UDK $577.1: 61$

ISSN 1452-8258

J Med Biochem 37: 328-335, 2018

Original paper

Originalni naučni rad

\title{
INFLUENCE OF IL-6, TNF- $\alpha$ AND hs-CRP ON INSULIN SENSITIVITY IN PATIENTS AFTER LAPAROSCOPIC CHOLECYSTECTOMY OR OPEN HERNIA REPAIR
}

\author{
UTICAJ IL-6, TNF- $\alpha$ I hs-CRP NA INSULINSKU SENZITIVNOST KOD BOLESNIKA \\ POSLE LAPAROSKOPSKE HOLECISTEKTOMIJE ILI OTVORENE OPERACIJE KILE
}

\author{
Dušan Micić1,2, Nebojša Lalić1,3, Vladimir Djukić1,2, Sanja Stanković4, \\ Goran Trajković ${ }^{1,5}$, Branislav Oluić2 ${ }^{2}$ Snežana Polovina ${ }^{3}$ \\ ${ }^{1}$ Faculty of Medicine, University of Belgrade, Belgrade, Serbia \\ ${ }^{2}$ Clinic for Emergency Surgery, Emergency Center, Clinical Center of Serbia, Belgrade, Serbia \\ ${ }^{3}$ Clinic for Endocrinology, Diabetes and Diseases of Metabolism, Clinical Center of Serbia, Belgrade, Serbia \\ ${ }^{4}$ Center for Medical Biochemistry, Clinical Center of Serbia, Belgrade, Serbia \\ ${ }^{5}$ Department for Medical Statistics and Informatics, Faculty of Medicine, University of Belgrade, Serbia
}

\section{Summary}

Background: The aim of this study was to investigate the influence of IL-6, TNF- $\alpha$ and hs-CRP on insulin sensitivity during postoperative follow-up in patients with laparoscopic cholecystectomy (LC) or open hernia repair (OHR).

Methods: 65 patients were studied: after laparoscopic cholecystectomy $(\mathrm{LC} ; \mathrm{n}=40)$ or open hernia repair (OHR; $n=25)$. Glucose, insulin, hs-CRP, IL- 6 and TNF- $\alpha$ were determined at day 0 (before the operation) and at days 1, 3 and 7 (after the operation).

Results: There were no difference between LC and OHR groups concerning age, BMI, glucose, insulin, hs-CRP, IL-6 and TNF- $\alpha$ at day 0 . hs-CRP increased at day 1, 3 and 7 vs. day $0(p<0.0005)$, without difference between groups $(p=0.561)$. IL-6 increased at day 1 and day 3 vs. day 0 $(p<0.005)$. IL- 6 was higher at day 1 in OHR group in comparison with LC group $(p=0.044)$. There were no differences in TNF- $\alpha$ levels between LC and OHR groups $(p=0.056)$. There was increase of HOMA-IR at day 1, 3 and 7 vs. day $0(p<0.0005)$ in both groups. Significantly higher increase of HOMA-IR was in OHR group compared

\begin{abstract}
Kratak sadržaj
Uvod: Cilj ove studije je bio ispitivanje uticaja sistemskih nivoa IL-6, TNF- $\alpha$ i hs-CRP na insulinsku senzitivnost tokom postoperativnog praćenja kod bolesnika sa laparoskopskom holecistektomijom (LH) ili otvorenom operacijom kile (OOK).

Metode: 65 bolesnika je ispitivano: posle laparoskopske holecistektomije (Grupa LH; n=40) ili otvorene operacije kile (Grupa OOK; $n=25$ ). Glukoza, insulin, hs-CRP, IL-6 i TNF- $\alpha$ su određivani 0 dana (pre operacije) i 1, 3 i 7 dana (posle operacije).

Rezultati: Nije bilo razlike $u$ početnim vrednostima između LH i OOK grupe za starost, BMI, glukozu, insulin, hs-CRP, IL-6 i TNF- $\alpha$ u 0-tom danu. hs-CRP se značajno povećao u danima 1,3 i 7 vs. dan 0 ( $p<0,0005)$, bez razlike među grupama $(p=0,561)$. IL-6 se značajno povećao 1 i 3 dana u odnosu na 0 dan $(p<0,0005)$. IL-6 je bio veći prvog dana u OOK grupi $(p=0,044)$. Nije bilo razlike u TNF- $\alpha$ između grupa $(p=0,056)$. HOMA-IR se značajno povećala u grupi OHR u poređenju sa LH grupom prvog postoperativnog dana $(p=0,045)$. U OOK grupi postojala je prvog
\end{abstract}

\footnotetext{
Address for correspondence:

Dusan Micić

Clinic for Emergency Surgery

Emergency Center

Clinical Center of Serbia

Pasterova 2, 11000 Belgrade

Phone number: 3811136622253

Fax number: 381113662257

e-mail: ducamicic@yahoo.com
}

List of abbreviations: hs-CRP, high sensitive $C$ reactive protein; IL-6, interleukin-6; TNF- $\alpha$, tumor necrosis factoralpha; HOMA-IR, homeostasis model assessment - insulin resistance; LC, laparoscopic cholecystectomy; OHR, oen hernia repair. 
with LC group at day $1(p=0.045)$. There was a positive correlation between hs-CRP and HOMA-IR ( $r=0.46$; $\mathrm{p}=0.025)$ and between IL- 6 and HOMA-IR at day 1 in OHR group $(r=0.44 ; p=0.030)$.

Conclusions: Significantly higher HOMA-IR was found in OHR group compared with LC. Positive correlation between hs-CRP and IL- 6 with HOMA-IR in OHR group at day 1 , indicate possible influence of this mediators on impairment of insulin sensitivity.

Keywords: HOMA-IR, hs-CRP, IL-6, TNF- $\alpha$, surgery

\section{Introduction}

Metabolic and inflammatory response is a part of overall stress response on surgical trauma and magnitude of this response depends of severity of the tissue damage (1). Surgical stress develops before, during and after operation as a result of psychological reaction, tissue injury, anesthetic agents and impaired local circulation $(2,3)$. Surgical trauma elicits marked changes in cytokine levels, impaired metabolic response and increase of acute phases proteins (4). Inflammatory response of the body in perioperative period is a protective mechanism which promotes better recovery, while excessive inflammatory response in severe tissue injury could contribute to development of complications and impaired wound healing (5). During the adaptation on surgical stress negative nitrogen balance provokes peripheral fat utilization and leads to increase in glucose production. The main underlying mechanism for hyperglycemia in perioperative period is development of insulin resistance. Previously it was shown that even a minor surgery could lead to a transient insulin resistance (6, 7).

Tumor necrosis factor- $\alpha$ (TNF- $\alpha$ ), interleukin-6 (IL-6) and $\mathrm{C}$-reactive protein (CRP) are, among the others, major regulators of the acute phase response to inflammation and tissue injury (8). Inflammatory response that is mediated by cytokines could be one of the molecular triggers for the metabolic response to surgery (9). TNF- $\alpha$ expression is considered as connection between fat mass, inflammation and decrease in insulin sensitivity (10). TNF- $\alpha$ plays one of a key roles in the acute phase response and induces lipolysis and muscle metabolism and it is also responsible for postoperative cachexia (11). Macrophages, neutrophils and some other types of cell are able to product TNF- $\alpha$ which as a cell signaling protein, contributes to weight loss, reduction of appetite, insulin resistance, impaired protein, glucose and lipid metabolism (12). IL-6 is inducer of inflammatory proteins such as CRP. CRP as protein of acute phase starts to increase 4-6 hours after tissue trauma with peak at 48 hours and decreasing gradually after 72 hours after uncomplicated surgical procedure. Concentrations of IL-6 and CRP in serum depends of magnitude of surgical intervention (4). A correlation between alterations in IL- 6 levels and the development of insulin resistance have been established in many studies. Also, it was demonstrated that postoperative insulin resistance as a part of metabolic response to surgery correlates with elevated levels of proinflammatory cytokines (13).

In early postoperative phase, glucose uptake in peripheral tissue dramatically declines. Lower glucose uptake correlates with magnitude of surgical trauma. Insulin resist- dana pozitivna korelacija između hs-CRP i HOMA-IR $(r=0,46 ; p=0,025)$ i između IL-6 i HOMA-IR $(r=0,44$ $p=0,030)$.

Zaključak: Značajno veća HOMA-IR je nađena u OOK grupi u poređenju sa LH grupom. Pozitivna korelacija između hs-CRP i IL-6 sa HOMA-IR u OOK grupi prvog postoperativnog dana ukazuje na mogući uticaj ovih medijatora na oštećenje insulinske senzitivnosti.

Ključne reči: HOMA-IR; hs-CRP; IL-6;TNF- $\alpha$, hirurgija

ance during surgical stress occurs as a consequence of elevated fatty acid concentrations, increased liver glucose production and decreased muscle glucose uptake (14). Insulin resistance followed by hyperglycemia after surgical procedure could be one of a possible independent factor for appearance of early and late postoperative complications (15). Serum glucose increment was demonstrated in open as well as in laparoscopic surgical procedures, but increment was lower in laparoscopic operation (16). Glucose metabolism became normal immediately after patients recovery (17).

Relationship between inflammation and insulin resistance in humans is still under the investigation, since much of the data is from rodent models and it was suggested recently, that more learning about that relationship is necessary (18).

Cholecystectomy as an intra-abdominal procedure causes major surgical stress. Laparoscopic approach minimizes peritoneal incision and reduces surgical stress. On the other hand, open hernia repair is followed by greater skin damage but there is not peritoneal incision (19). The aim of our study was to investigate the influence of systemic levels of IL-6, TNF- $\alpha$ and CRP on insulin sensitivity during postoperative follow-up in laparoscopic cholecystectomy and open hernia repair, two types of elective surgery operations with different skin and peritoneal injury.

\section{Materials and Methods}

The non-randomized, prospective, time-related study was performed on 65 patients with laparoscopic cholecystectomy (LC) or open hernia repair (OHR). The study was performed in Clinic for Emergency Surgery in Clinical Center of Serbia in Belgrade, after getting approval of Ethical Committee of Faculty of Medicine, University of Belgrade (No. 29/IV-11). Study was conducted according to the Helsinki Declaration and each patient gave written informed consent to participate in the study. Inclusion criteria were: patients undergoing elective laparoscopic cholecystectomy or elective open hernia repair. Exclusion criteria were known diabetes type I or type II, heart, liver or renal failure (serum creatinine over $150 \mathrm{mmol} / \mathrm{L}$ ), mental diseases, existing malignancy and severe infection. All the patients were operated in a period between 2015-2017. Laparoscopic cholecystectomy was performed in 40 patients and open hernia repair in 25 patients. Baseline characteristics of the groups are presented in Table $I$.

Glucose, insulin, hs-CRP, IL- 6 and TNF- $\alpha$ were determined at day 0 (before the operation) and at days 1,3 and 7 (after the operation), after overnight fasting. Glucose was 
Table I Baseline characteristics of studied population.

\begin{tabular}{|l|c|c|c|}
\hline Variable & $\begin{array}{c}\text { LC Group } \\
(\mathrm{n}=40)\end{array}$ & $\begin{array}{c}\text { OHR Group } \\
(\mathrm{n}=25)\end{array}$ & $\mathrm{p}$ \\
\hline Age $^{*}, \mathrm{yrs}$ & $52.3 \pm 14.2$ & $47.8 \pm 17.7$ & 0.262 \\
\hline Male sex, $\mathrm{n}(\%)$ & $22(55)$ & $22(88)$ & 0.006 \\
\hline $\mathrm{BMI}^{*}, \mathrm{~kg} / \mathrm{m}^{2}$ & $25.1 \pm 1.4$ & $25.1 \pm 0.5$ & 0.912 \\
\hline Glucose $^{*}, \mathrm{mmol} / \mathrm{L}$ & $4.7 \pm 0.9$ & $4.5 \pm 0.8$ & 0.239 \\
\hline Insulin $^{* *}, \mu \mathrm{U} / \mathrm{mL}$ & $6.9(4.6)$ & $6.3(4.8)$ & 0.751 \\
\hline $\mathrm{HOMA-IR}^{* *}$ & $1.4(1.2)$ & $1.3(1.3)$ & 0.824 \\
\hline hs-CRP**, $\mathrm{mg} / \mathrm{L}$ & $3.3(6.7)$ & $2.0(1.5)$ & 0.082 \\
\hline IL-6** ${ }^{*} \mathrm{pg} / \mathrm{mL}$ & $6.1(5.6)$ & $4.1(4.7)$ & 0.567 \\
\hline TNF- $\alpha^{* *}, \mathrm{pg} / \mathrm{mL}$ & $1.3(1.1)$ & $1.1(0.8)$ & 0.195 \\
\hline
\end{tabular}

* Data are presented as mean \pm standard deviation

**Data are presented as median with interquartile range LC: Laparoscopic cholecystectomy

OHR: Open hernia repair

measured using commercial assay on Roche Cobas 6000 automated analyzer (Roche Diagnostics, Manheim, Germany). Reference range for glucose was $3.9-6.1 \mathrm{mmol} / \mathrm{L}$. The serum high-sensitive $\mathrm{C}$-reactive protein (hs-CRP) concentration was measured using commercial assays on Roche Cobas 6000 automated analyzer. Reference range for hs-CRP was $0-10 \mathrm{mg} / \mathrm{L}$. The serum insulin measurement was done by an electrochemiluminescence immunoassay on Roche Cobas 6000 automated analyzer. Insulin assay has a measurement range of $0.20-1000 \mathrm{mU} / \mathrm{mL}$ with a limit of detection of $0.20 \mathrm{mU} / \mathrm{mL}$. The validation of the Roche Insulin assay in our laboratory revealed intra- and inter-assay coefficients of variation between $1.0 \%$ and $4.5 \%$. Reference value for fasting insulin was $<25 \mathrm{mU} / \mathrm{L}$. IL-6 measurement was done by an electrochemiluminescence immunoassay on Roche Cobas 6000 automated analyzer (Roche Diagnostics, Mannheim, Germany). According to the manufacturer's package insert, Roche Cobas II-6 reagent kit (Roche Diagnostics $\mathrm{GmbH}$, Germany) had a measurement range of 1,5-5000 pg/mL with a limit of detection of $1.5 \mathrm{pg} / \mathrm{mL}$. The Roche IL-6 assay revealed intra- and inter-assay coefficients are lower than $5.3 \%$. The TNF- $\alpha$ levels were measured using commercially available the Human TNF- $\alpha$ Quantikine HS ELISA (R\&D Systems Europe, UK) on ETI-Max 3000 (Diasorin S.p.A., Italy). The lower detection limit of this ELISA assay is $0.191 \mathrm{pg} / \mathrm{mL}$ and reported intra- and inter-assay coefficients of variation are lower than $10.4 \%$.

Homeostatic model assessment-insulin resistance (HOMA-IR) is based on fasting glucose and insulin levels and the index is calculated as follows: HOMA-IR $=$ Go $\times$ lo/22.5, where $\mathrm{Go}=$ fasting glucose concentration $(\mathrm{mmol} / \mathrm{L})$, lo fasting plasma insulin concentration $(\mathrm{mU} / \mathrm{mL})$ (20).

Quantitative variables with normal distribution are expressed as mean values with standard deviations. Medians with interquartile ranges (IQRs) were used to present data without normal distribution.
Kolmogorov-Smirnov test was used to assess the distribution of data. Categorical data are presented by absolute and relative frequencies. Baseline characteristics between groups were compared using the Student t-test or the Mann-Whitney test. Changes in examined variables from baseline to the $1^{\text {st }}, 3^{\text {rd }}$ and $7^{\text {th }}$ day were evaluated by general linear model for repeated measures with the cholecystectomy or open hernia repair operations as betweensubjects factor. Changes in examined variables according to study groups are presented by boxplot. Correlation between variables was evaluated with Pearson or Spearman correlation coefficient according to data distribution. Statistical analysis was performed using SPSS statistical software (SPSS for Windows, release 21.0, SPPSS, Chicago, IL). In all test, $\mathrm{p}$ value $<0.05$ was considered to be statistically significant.

\section{Results}

Baseline characteristics of the studied patients are presented in Table I. Patients with laparoscopic cholecystectomy are included in LC group $(n=40)$, patients with open hernia repair are included in OHR group $(n=25)$. There was no significant difference between studied groups at baseline concerning age $(p=0.262), B M I(p=0.912)$, glucose $(p=0.239)$, insulin $(p=0.751)$, hs-CRP $(p=0.082)$, IL-6 $(p=0.567)$ and TNF- $\alpha(p=0.195)$. In OHR group there were more males, than females due to rarity of inguinal hernia in females. HOMA-IR index did not differ at day 0 between the groups (median values: 1.4 in LC group and 1.3 in OHR group) ( $p=0.824)$. Changes in glucose, insulin, HOMA-IR, hs-CRP, IL- 6 and TNF- $\alpha$ during the study period (from day 0 to day 7 ) are presented in Table II. Glucose values increased at day 1, day 3 and day 7 without statistical significance $(p=0.062)$ in comparison with day 0 in both groups. There were no differences in glucose level between two groups $(p=0.176)$. Serum insulin increased significantly at day 1,3 and day 7 compared with day $0(p<0.0005)$ in both groups. Serum insulin reached maximum level at day 1 and declined gradually to day 7 . There was no significant difference between two groups $(p=0.085)$. hs- CRP increased significantly at day 1,3 and 7 in comparison with day 0 in LC and OHR group $(p<0.0005)$. There were no difference in hs-CRP values between $\mathrm{LC}$ and $\mathrm{OHR}$ group $(p=0.561)$. IL-6 values increased significantly at day 1 and day 3 compared with baseline values in LC and OHR group $(p<0.0005)$. IL-6 was significantly higher at day 1 in OHR group $(p=0.044)$ in comparison with LC group. TNF- $\alpha$ increased significantly at day 1 and day 3 compared with day 0 in both groups $(p<0.0005)$. There were no differences among TNF- $\alpha$ levels in LC and OHR group (day 1: $p=0.376$; day 3: $p=0.189$; day $7: p=0.231$ ).

HOMA-IR values increased significantly at day 1 , day 3 and day 7 compared with day $0(p<0.0005)$ in both groups. There was significantly higher HOMA-IR in OHR group compared with LC group at day $1(p=0.045)$ (Figure 1). There were no differences in HOMA-IR between groups for day $3(p=0.278)$ and day $7(p=0.372)$.

There was a positive correlation between hs-CRP and HOMA-IR ( $r=0.46 ; p=0.025)$ and between IL-6 and HOMA-IR at day 1 in OHR group $(r=0.44 ; p=0.030)$ (Figure 2 and Figure 3). 
Table II Changes in glucose, insulin, HOMA-IR, hs-CRP, IL- 6 and TNF- $\alpha$ during the study period.

\begin{tabular}{|c|c|c|c|c|}
\hline & Baseline & Day 1 & Day 3 & Day 7 \\
\hline \multicolumn{5}{|c|}{ Glucose*, mmol/L } \\
\hline LC & $4.75 \pm 0.86$ & $5.05 \pm 1.15$ & $4.95 \pm 1.01$ & $4.77 \pm 0.72$ \\
\hline $\mathrm{OHR}$ & $4.49 \pm 0.79$ & $4.78 \pm 0.99$ & $4.79 \pm 0.66$ & $4.56 \pm 0.46$ \\
\hline \multicolumn{5}{|c|}{ Insulin**, $\mu \mathrm{U} / \mathrm{mL}$} \\
\hline LC & $6.9(4.6)$ & $11.7(8.0)$ & $8.9(7.5)$ & $7.6(4.7)$ \\
\hline $\mathrm{OHR}$ & $6.3(4.8)$ & $12.8(9.3)$ & $9.1(4.9)$ & $7.0(20.3)$ \\
\hline \multicolumn{5}{|c|}{ HOMA-IR** } \\
\hline LC & $1.4(1.2)$ & $2.3(1.8)$ & $1.9(1.7)$ & $1.6(1.2)$ \\
\hline $\mathrm{OHR}$ & $1.3(1.3)$ & $2.8(2.9)$ & $2.1(4.1)$ & $1.4(3.8)$ \\
\hline \multicolumn{5}{|c|}{$\mathrm{hs}-\mathrm{CRP}{ }^{* *}, \mathrm{mg} / \mathrm{L}$} \\
\hline LC & $3.3(6.7)$ & $13.0(26.3)$ & $25.8(44.7)$ & $9.0(25.8)$ \\
\hline $\mathrm{OHR}$ & $2.0(1.5)$ & $15.7(25.4)$ & $26.0(37.7)$ & 9.5 (14.9) \\
\hline \multicolumn{5}{|c|}{$\mathrm{IL6**}, \mathrm{pg} / \mathrm{mL}$} \\
\hline LC & $6.1(5.6)$ & 10.3 (17.7) & $8.6(10.3)$ & $5.3(4.8)$ \\
\hline $\mathrm{OHR}$ & $4.1(4.7)$ & $16.1(23.5)$ & $9.3(5.7)$ & $4.4(3.1)$ \\
\hline \multicolumn{5}{|c|}{ TNF- $\alpha^{* *}, \mathrm{pg} / \mathrm{mL}$} \\
\hline LC & $1.3(1.1)$ & $2.3(1.6)$ & $1.3(1.5)$ & $1.0(0.6)$ \\
\hline $\mathrm{OHR}$ & $1.1(0.8)$ & $1.5(1.5)$ & $1.1(0.5)$ & $0.8(0.4)$ \\
\hline
\end{tabular}

* Data are presented as mean \pm standard deviation; **Data are presented as median with interquartile range LC: Laparoscopic cholecystectomy; OHR: Open hernia repair

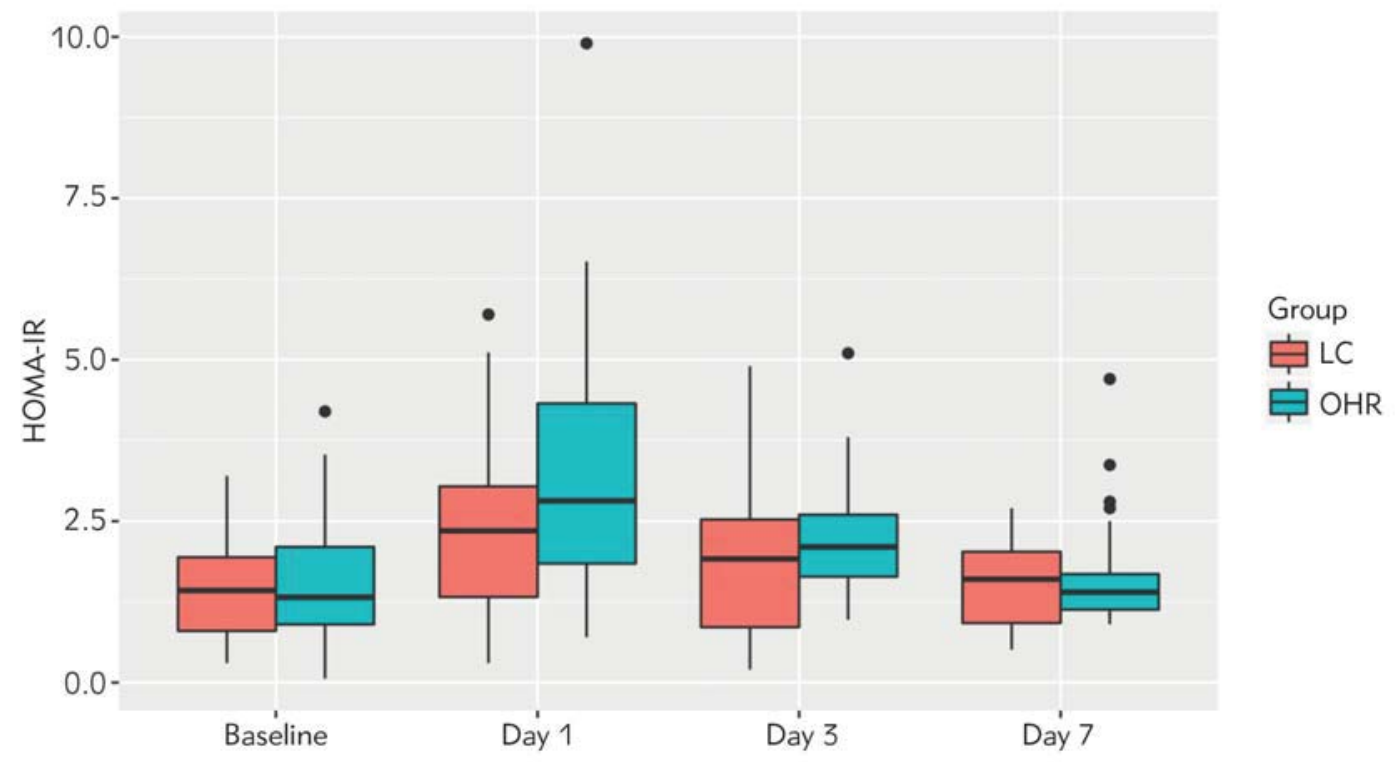

Figure 1 Change in HOMA-IR at day $0,1,3$ and 7. 


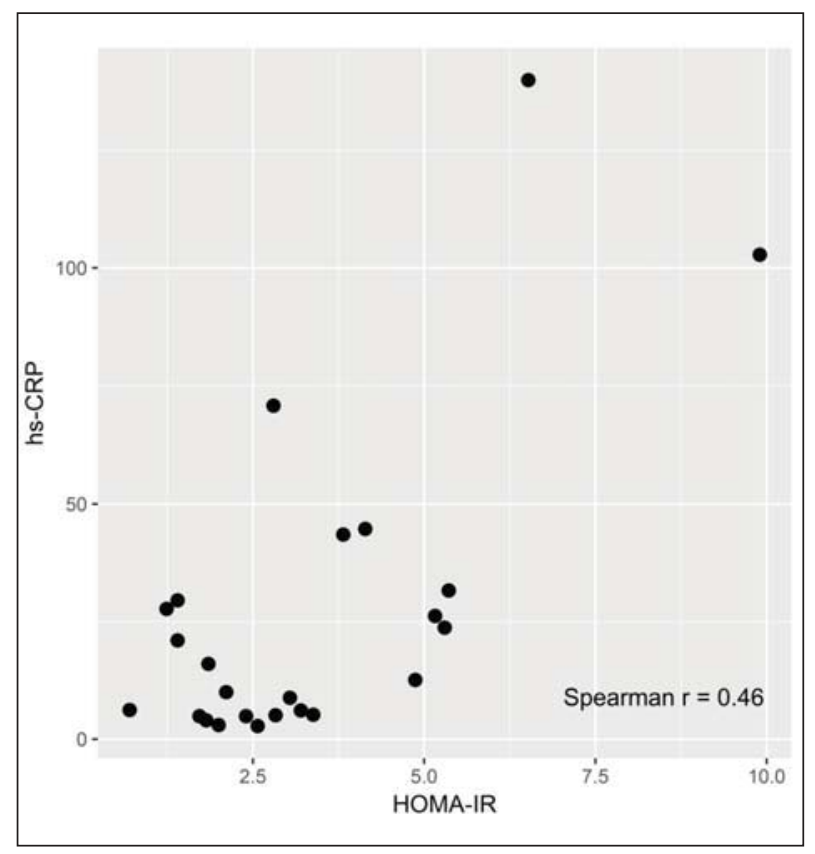

Figure 2 Correlation between HOMA-IR and hs-CRP at day 1

\section{Disscusion}

The surgical trauma induces inflammatory, metabolic and neurohormonal response. Previous investigations demonstrated that laparoscopic surgery is superior to open surgery concerning the metabolic changes (21). The response on surgical trauma depends of severity of the tissue damage (1). Metabolic impairment such as insulin resistance develops after elective surgical procedures and persists approximately 5 days after surgery (22). In our study increase in HOMA-IR was greater in open hernia repair in comparison with laparoscopic cholecystectomy.

Earlier investigations indicated that the level of IL-6, as pro inflammatory cytokine, increases already after 60 minutes after surgical trauma with peak at 12-24 hours, and decreases $48-72$ hours after operations without complications. This cytokine is the first released in the cytokine cascade (23). We achieved compatible results in our patients; IL- 6 achieved peak value at first postoperative day and decreased during next few days. In our study, the level of IL-6 was higher in patients undergoing open surgery. Some authors reported lack of any differences in IL-6 concentrations between laparoscopic and open surgery (24), although some other investigators demonstrated that the level of IL-6 was lower in laparoscopic in comparison with open surgery and that was shown in different operations such as hysterectomy, hernia repair, cholecystectomy and vascular operations $(16,21,25-31)$. Skin incision was found to be the impulse for cytokine release and laparoscopic surgery is followed by less tissue injury and less inflammation than open approach. The other authors have shown that IL-6 levels correlate with the surgical tissue damage and duration of operation, suggesting therefore that this marker could be useful to chose most appropriate surgical method (32).

Previous studies demonstrated that kinetic of IL-1, TNF- $\alpha$ and IL- 6 is quite similar, and all of them achieved

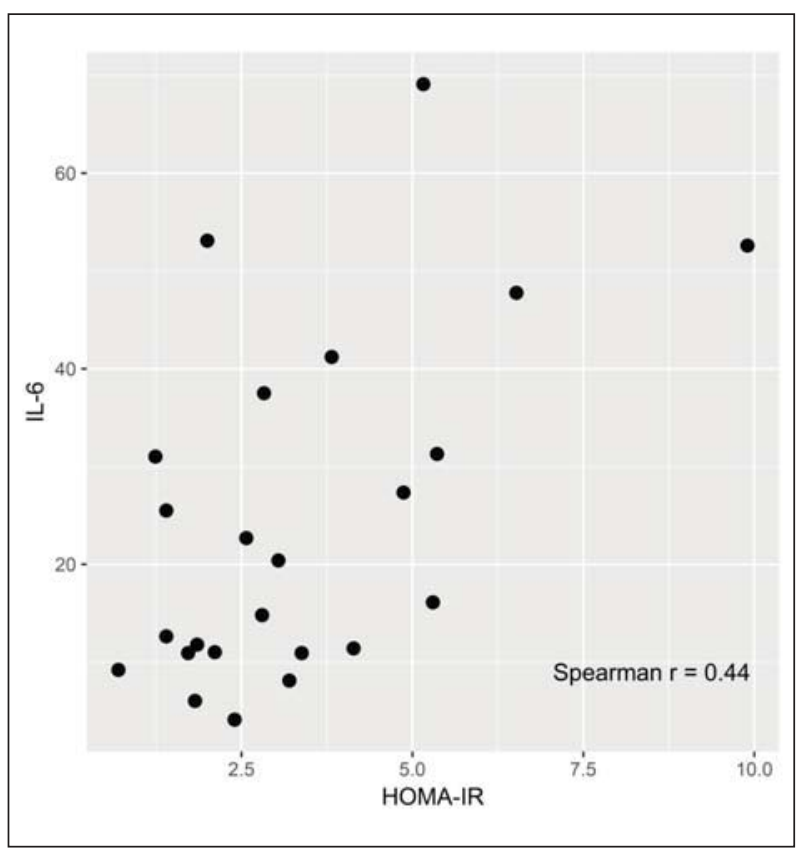

Figure 3 Correlation between HOMA-IR and IL-6 at day 1

highest values 24 hours after surgery and normalized 7 days after operation, as we found among our patients. Cytokine levels were higher in the open than in the laparoscopic surgery (27). Different values of IL-6 were found after major abdominal operation such as elective aortic surgery in comparison with open hernia repair. In both groups levels of IL-6 decreased sharply within 48-72h but concentration of IL- 6 was lower after hernia repair. Authors presumed that these difference in IL-6 concentrations correlates with ischemia and changes in blood pressure during the aortic surgery (26). In some cases, predominantly in patients with preoperative high level of IL-6, this cytokine remained elevated at least 14 days after surgery. In these patients persistent elevation of IL- 6 could be associated with psychological stress and preoperative anxiety in operating theatre (33). It was suggested that perioperative measurement of IL- 6 can be useful for identifying patients with higher risk of complications (26).

TNF- $\alpha$ induces lipolysis, muscular catabolism, stimulates coagulation and release of adhesion molecules (11). In our study levels of TNF- $\alpha$ achieved peak value at first postoperative day and decreased continuously till day 7 when returned on preoperative values. We did not find significant differences between LC and OHR group concerning TNF- $\alpha$ level. Similar results were published by other investigators who demonstrated lack of differences in TNF$\alpha$ levels after laparoscopic and open hernia repair $(13,18)$ as well as after laparoscopic and open cholecystectomy (30, 35). Lahat et al. (36) reported similar increase of TNF- $\alpha$ after open cholecystectomy or after coronary arter y bypass grafting (CABG), but TNF- $\alpha$ level was higher in a group with CABG, probably due to more tissue damage. Some authors reported significant reduction in TNF- $\alpha, \mathrm{IFN}-\gamma$ and IL-2 after open procedures in comparison with laparoscopic cholecystectomy (37), while others described greater increase of IL- 6 and TNF- $\alpha$ after open cholecystectomy in comparison with laparoscopic cholecystectomy (38). 
CRP as protein of acute phase starts to increase 4-6 hours after tissue trauma with peak at 48 hours and falls gradually after 72 hours after uncomplicated surgical procedure. Concentrations of IL-6 and CRP in serum depends of magnitude of surgical intervention and its invasiveness $(4,23,39)$. Delayed increase of CRP in comparison with the increase in IL- 6 suggests that CRP is less powerful predictive marker for surgical complications (26). On the other hand, fail in decrease in CRP levels within 48h after operation is followed by more increase in IL- 6 and indicate higher risk for postoperative complications (40). Shorter preoperative fasting time is associated with less increase of CRP, reduction in insulin resistance and reduction in stress response (41). In our study CRP increased at first and third day after operation and decreased at almost preoperative value seven days after the operation. Pinato et al. (40) suggested age-related delay in CRP clearance due to unopposed IL-6 release in elderly patients.

The maximum reported values of CRP after surgery vary between $52 \mathrm{mg} / \mathrm{L}$ after cholecystectomy up to 163 $\mathrm{mg} / \mathrm{L}$ after aortic aneurism repair (4). Takahara et al. (42) reported higher CRP values after laparoscopic then in open hernia repair. Some other authors have shown that levels of CRP were equal in both surgical approaches $(24,43)$.

In early postoperative phase, glucose uptake in peripheral tissue dramatically declines. Lower glucose uptake correlates with magnitude of surgical trauma. Insulin resistance during surgical stress occurs due to elevated fatty acid concentrations, increased liver glucose production and decreased muscle glucose uptake (14). In our study insulin increase was observed at day 1 and day 3 in both groups. However, insulin increase was greater in OHR group in comparison with LC group. Also, we found impairment of insulin sensitivity in early postoperative period in both groups. HOMA-IR increase was significantly higher in a OHR group than in LC group. HOMA-IR was normalized seven days after surgery in both groups. Insulin resistance was found to be an independent factor for surgery outcomes and length of stay in hospital (44). Previously, in a study performed among patients undergoing open chole-

\section{References}

1. Desborough JP. The stress response to trauma and surgery. Br J Anaesth 2000; 85(1): 109-17.

2. Wilmore DW. From Cuthbertson to fast-track surgery: 70 years of progress in reducing stress in surgical patients. Ann Surg 2002; 236(5): 643-8.

3. Finnerty CC, Mabvuure NT, Ali A, Kozar RA, Herndon $D N$. The surgically induced stress response. JPEN J Parenter Enteral Nutr 2013; 37: Suppl 5: 21S-9S.

4. Watt DG, Horgan PG, McMillan DC. Routine clinical markers of the magnitude of the systemic inflammatory response after elective operation: a systematic review. Surgery 2015; 157(2): 362-80.

5. Mijatović S, Alempijević T, Stefanović B, Jeremić V, Krstić S, Radmanović N, Jovanović S, Stefanović B. Influence of syrgical trauma on nitric oxide and nitrotyrosine serum levels in patients undergoing laparoscopic or conventional cholecystectomy. J Med Biochem 2017; 36: 171-6. cystectomy and open hernia repair it was reported that dynamic changes of IL- 6 and markers of insulin resistance in postoperative period could be in relationship (6). In our investigation we have found correlation between hs-CRP and HOMA- IR and between IL-6 and HOMA-IR in OHR group at day 1 . These findings may indicate that postoperative increase of cytokines may be interrelated with the observed impairment of insulin sensitivity, demonstrated through the increase of HOMA-IR. Comparison between open and laparoscopic cholecystectomy demonstrated less postoperative reduction of insulin sensitivity as beneficial factor for faster recovery after laparoscopic procedure (45). In early investigations, marked insulin resistance was suggested as a consequence of major abdominal surgery irrespective of surgical technique (46).

Limitation of our study was the relative limited number of patients and further studies are necessary to confirm our findings.

In conclusion, we demonstrated in our patients after laparoscopic cholecystectomy or open hernia repair a transitory increase of inflammatory markers such as hs-CRP, IL6 and TNF- $\alpha$ with simultaneously increase in HOMA-IR as an index of insulin resistance. Open surgery procedures produce greater increase of observed cytokines and greater impairment of insulin sensitivity. HOMA-IR significantly increased at day 1 in OHR group in comparison with LC group. Correlations that was found between hs-CRP and HOMA-IR and IL-6 and HOMA-IR at day 1 in OHR group indicate possible influence of these mediators on the impairment of insulin sensitivity. Further studies are necessary to confirm these observations. Laparoscopic approach causes less surgical stress, less increase of cytokines and less impairment of insulin sensitivity which may be beneficial factor for faster postoperative recovery.

\section{Conflict of interest statement}

The authors stated that they have no conflicts of interest regarding the publication of this article.

6. Thorell A, Loftenius A, Andersson B, Ljungqvist $O$. Postoperative insulin resistance and circulating concentrations of stress hormones and cytokines. Clin Nutr 1996; 15(2): 75-9.

7. Viganò J, Cereda E, Caccialanza R, Carini R, Cameletti B, Spampinato $M$, et al. Effects of preoperative oral carbohydrate supplementation on postoperative metabolic stress response of patients undergoing elective abdominal surgery. World J Surg 2012; 36(8): 1738-43.

8. Sari R, Sevinc A. The effects of laparascopic cholecystectomy operation on C-reactive protein, hormones, and cytokines. J Endocrinol Invest 2004; 27(2): 106-10.

9. Lingohr P, Dohmen J, Matthaei H, Konieczny N, Hoffmann J, Bölke E, et al. Cytokine expression in the visceral adipose tissue after laparoscopic and conventional surgery in a rodent model. Eur J Med Res 2016; 21: 4.

10. Witasp A, Nordfors L, Schalling M, Nygren J, Ljungqvist $\mathrm{O}$, Thorell A. Expression of inflammatory and insulin sig- 
naling genes in adipose tissue in response to elective surgery. J Clin Endocrinol Metab 2010; 95(7): 3460-9

11. Borges Mde C, Terra GA, Takeuti TD, Ribeiro BM, Silva AA, Terra-Júnior JA, et al. Immunological evaluation of patients with type 2 diabetes mellitus submitted to metabolic surgery. Arq Bras Cir Dig 2015; 28(4): 266-9.

12. Patel HJ, Patel BM. TNF- $\alpha$ and cancer cachexia: Molecular insights and clinical implications. Life Sci 2017; 170: 56-63.

13. Kim J, Bachmann RA, Chen J. Chapter 21 Interleukin 6 and Insulin Resistance. In: Litwack G, editor. Vitamins and hormones. Amsterdam: Elsevier, 2009: 613-33.

14. Ljungqvist O, Nygren J, Soop M, Thorell A. Metabolic perioperative management: novel concepts. Curr Opin Crit Care 2005; 11(4): 295-9.

15. Baban B, Thorell A, Nygren J, Bratt A, Ljungqvist $O$. Determination of insulin resistance in surgery: the choice of method is crucial. Clin Nutr 2015; 34(1): 123-8.

16. Joris J, Cigarini I, Legrand $M$, Jacquet $N$, De Groote $D$, Franchimont $\mathrm{P}$, Lamy M. Metabolic and respiratory changes after cholecystectomy performed via laparotomy or laparoscopy. Br J Anaesth 1992; 69(4): 341-5.

17. Gjessing PF, Constantin-Teodosiu D, Hagve M, Lobo DN, Revhaug A, Irtun $\varnothing$. Preoperative carbohydrate supplementation attenuates post-surgery insulin resistance via reduced inflammatory inhibition of the insulin-mediated restraint on muscle pyruvate dehydrogenase kinase 4 expression. Clin Nutr 2015; 34(6): 1177-83.

18. Hagman DK, Larson I, Kuzma JN, Cromer G, Makar K, Rubinow KB, et al. The short-term and long-term effects of bariatric/metabolic surgery on subcutaneous adipose tissue inflammation in humans. Metabolism 2017; 70: 12-22.

19. Jakeways MS, Mitchell V, Hashim IA, Chadwick SJ, Shenkin A, Green CJ, et al. Metabolic and inflammatory responses after open or laparoscopic cholecystectomy. $\mathrm{Br}$ J Surg 1994; 81(1): 127-31.

20. Matthews DR, Hosker JP, Rudenski AS, Naylor BA, Treacher DF, Turner RC. Homeostasis model assessment: insulin resistance and beta-cell function from fasting plasma glucose and insulin concentrations in man. Diabetologia 1985; 28(7): 412-9.

21. Kristiansson M, Saraste L, Soop M, Sundqvist KG, Thörne A. Diminished interleukin- 6 and C-reactive protein responses to laparoscopic versus open cholecystectomy. Acta Anaesthesiol Scand 1999; 43(2): 146-52.

22. Thorell A, Efendic S, Gutniak M, Häggmark T, Ljungqvist $O$. Insulin resistance after abdominal surgery. Br J Surg 1994; 81(1): 59-63.

23. Sweed Y, Puri P, Reen DJ. Early induction of IL-6 in infants undergoing major abdominal surgery. J Pediatr Surg 1992; 27(8): 1033-6.

24. Schrenk $P$, Bettelheim $P$, Woisetschläger R, Rieger $R$, Wayand WU. Metabolic responses after laparoscopic or open hernia repair. Surg Endosc 1996; 10(6): 628-32.

25. Vander Velpen G, Penninckx F, Kerremans R, Van Damme J, Arnout J. Interleukin-6 and coagulation-fibri- nolysis fluctuations after laparoscopic and conventional cholecystectomy. Surg Endosc 1994; 8(10): 1216-20.

26. Baigrie RJ, Lamont PM, Kwiatkowski D, Dallman MJ, Morris PJ. Systemic cytokine response after major surgery. Br J Surg 1992; 79(8): 757-60.

27. Bellón JM1, Manzano L, Bernardos L, Ga-Honduvilla N, Larrad A, Buján J, et al. Cytokine levels after open and laparoscopic cholecystectomy. Eur Surg Res 1997; 29(1): 27-34.

28. Bellón JM1, Manzano L, Larrad A, Honduvilla GN, Bujan J, Alvarez-Mon M. Endocrine and immune response to injury after open and laparoscopic cholecystectomy. Int Surg 1998; 83(1): 24-7.

29. Jess P, Schultz K, Bendtzen K, Nielsen OH. Systemic inflammatory responses during laparoscopic and open inguinal hernia repair: a randomised prospective study. Eur J Surg 2000; 166(7): 540-4.

30. Reith HB, Kaman S, Mittelkötter O, Kilic Y, Kozuschek W. Cytokine activation in patients undergoing open or laparoscopic cholecystectomy. Int Surg 1997; 82(4): 389-93.

31. Jawa RS, Anillo S, Huntoon K, Baumann H, Kulaylat M. Interleukin-6 in surgery, trauma, and critical care part II: clinical implications. J Intensive Care Med 2011; 26(2): 73-87.

32. Kim TK1, Yoon JR. Comparison of the neuroendocrine and inflammatory responses after laparoscopic and abdominal hysterectomy. Korean J Anesthesiol 2010; 59(4): 265-9

33. Bulbuller N, Kirkil C, Godekmerdan A, Aygen E, Ilhan YS. The Comparison of Inflammatory Responses and Clinical Results After Groin Hernia Repair Using Polypropylene or Polyester Meshes. Indian J Surg 2015; 77: Suppl 2: 283-7.

34. Akhtar K, Kamalky-asl ID, Lamb WR, Laing I, Walton L, Pearson RC, et al. Metabolic and inflammatory responses after laparoscopic and open inguinal hernia repair. Ann R Coll Surg Engl 1998; 80(2): 125-30.

35. Abu-Eshy SA, Moosa RA, Al-Rofaidi AA, Al-Faki AS, Sadik AA, Salati MI, et al. Proinflammatory cytokines in open versus laparoscopic cholecystectomy. Saudi Med J 2002; 23(4): 436-40.

36. Lahat N, Zlotnick AY, Shtiller R, Bar I, Merin G. Serum levels of IL-1, IL-6 and tumour necrosis factors in patients undergoing coronary artery bypass grafts or cholecystectomy. Clin Exp Immunol 1992; 89(2): 255-60.

37. Brune IB, Wilke W, Hensler T, Holzmann B, Siewert JR. Downregulation of $T$ helper type 1 immune response and altered pro-inflammatory and anti-inflammatory $\mathrm{T}$ cell cytokine balance following conventional but not laparoscopic surgery. Am J Surg 1999; 177(1): 55-60.

38. Haq Z, Rahman M, Siddique MA, Roy RK, Rahman AM, Khatun M. Interleukin-6 (IL-6) and tumour necrosis factor-alpha in open and laparoscopic cholecystectomy. Mymensingh Med J 2004; 13(2): 153-6.

39. Di Vita G, D'Agostino P, Patti R, Arcara M, Caruso G, Davì $\checkmark$, Cillari $E$. Acute inflammatory response after inguinal and incisional hernia repair with implantation of 
polypropylene mesh of different size. Langenbecks Arch Surg 2005; 390(4): 306-11.

40. Pinato DJ, Bains J, Irkulla S, Pomroy J, Ujam B, Gaze D, Mendall MA. Advanced age influences the dynamic changes in circulating $\mathrm{C}$-reactive protein following injury. J Clin Pathol 2013; 66(8): 695-9.

41. Xu D, Zhu X, Xu Y, Zhang L. Shortened preoperative fasting for prevention of complications associated with laparoscopic cholecystectomy: a meta-analysis. J Int Med Res 2017; 45(1): 22-37.

42. Takahara T, Uyama I, Ogiwara H, Furuta T, lida S. Inflammatory responses in open versus laparoscopic herniorrhaphy. J Laparoendosc Surg 1995; 5(5): 317-26.
43. Vats M, Pandey D, Saha S, Talwar N, Saurabh G, Andley $M$, Kumar A. Assessment of systemic inflammatory response after total extraperitoneal repair and Lichtenstein repair for inguinal hernia. Hernia 2017; 21(1): 65-71.

44. Ljungqvist $O$. Modulating postoperative insulin resistance by preoperative carbohydrate loading. Best Pract Res Clin Anaesthesiol 2009; 23(4): 401-9.

45. Thorell A, Nygren J, Essén P, Gutniak M, Loftenius A, Andersson $B$, et al. The metabolic response to cholecystectomy: insulin resistance after open compared with laparoscopic operation. Eur J Surg 1996; 162(3): 187-91.

46. Hawthorne GC1, Ashworth L, Alberti KG. The effect of laparoscopic cholecystectomy on insulin sensitivity. Horm Metab Res 1994; 26(10): 474-7.

Received: July 27, 2017

Accepted: August 12, 2017 